Prepared in cooperation with the Energy Resources and Groundwater Resources Programs

Digital Surfaces and Hydrogeologic Data for Mesozoic through Early Tertiary Rocks in the Southeastern Coastal Plain in Parts of Mississippi, Alabama, Georgia, South Carolina, and Florida

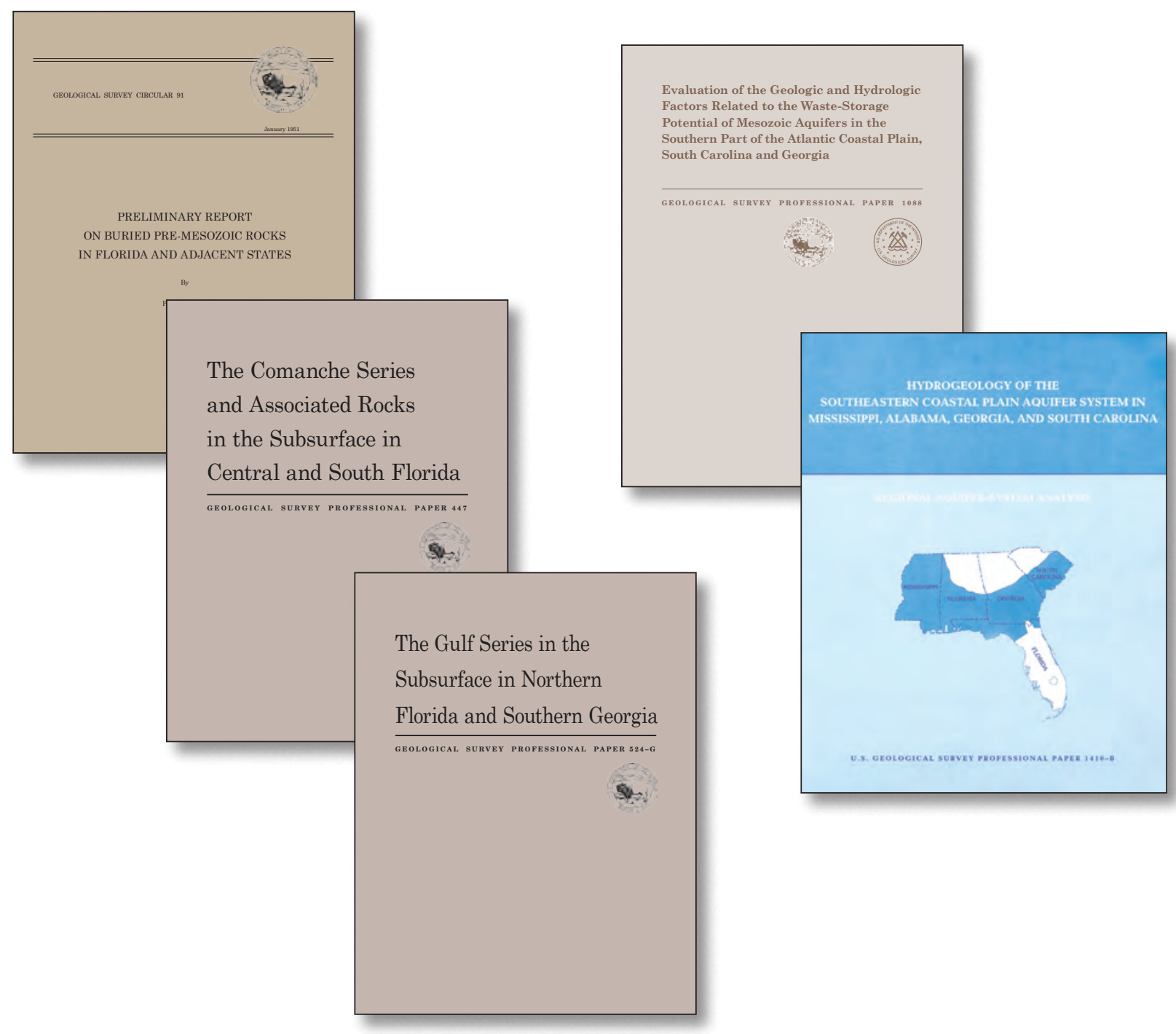

Data Series 662 
Cover. Cover images of publications used in this report.

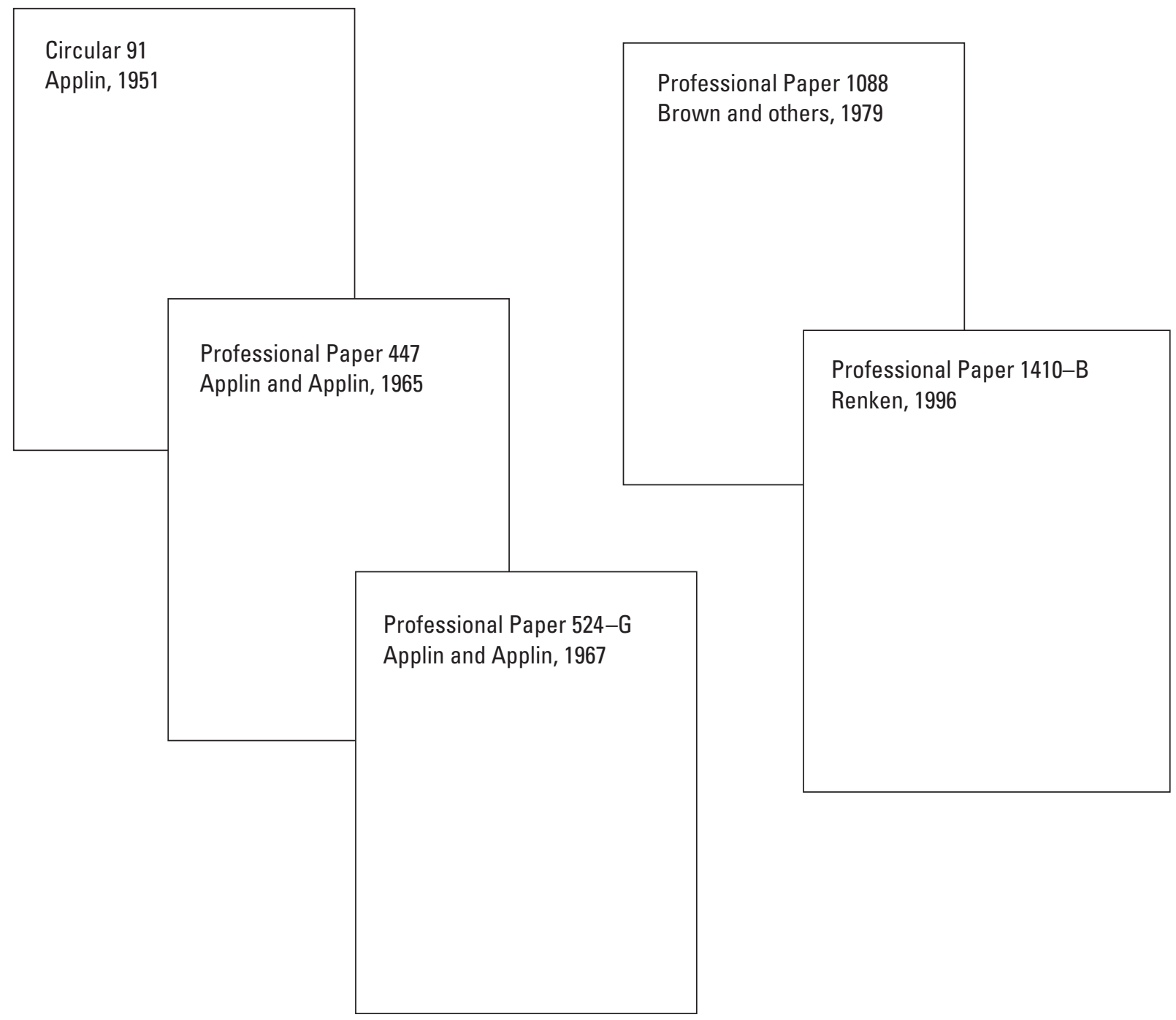




\section{Digital Surfaces and Hydrogeologic Data for Mesozoic through Early Tertiary Rocks in the Southeastern Coastal Plain in Parts of Mississippi, Alabama, Georgia, South Carolina, and Florida}

By Debra M. Cannon, Jason C. Bellino, and Lester J. Williams

Prepared in cooperation with the Energy Resources and Groundwater Resources Programs

Data Series 662 


\section{U.S. Department of the Interior \\ KEN SALAZAR, Secretary \\ U.S. Geological Survey \\ Marcia K. McNutt, Director}

\section{U.S. Geological Survey, Reston, Virginia: 2012}

For more information on the USGS - the Federal source for science about the Earth, its natural and living resources, natural hazards, and the environment, visit http://Www.usgs.gov or call 1-888-ASK-USGS

For an overview of USGS information products, including maps, imagery, and publications, visit $h$ ttp://www.usgs.gov/pubprod

To order this and other USGS information products, visit http://store.usgs.gov

Any use of trade, product, or firm names is for descriptive purposes only and does not imply endorsement by the U.S. Government.

Although this report is in the public domain, permission must be secured from the individual copyright owners to reproduce any copyrighted materials contained within this report.

Suggested citation:

Cannon, D.M., Bellino, J.C., and Williams, L.J., 2012, Digital surfaces and hydrogeologic data for the Mesozoic through early Tertiary rocks in the Southeastern Coastal Plain in parts of Mississippi, Alabama, Georgia, South Carolina, and Florida: U.S. Geological Survey Data Series 662, 13 p.; available at http://pubs.usgs.gov/ds/662/. 


\section{Contents}

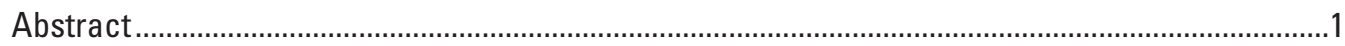

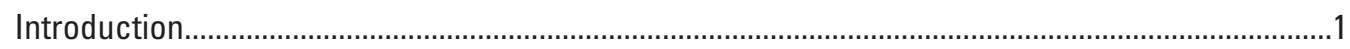

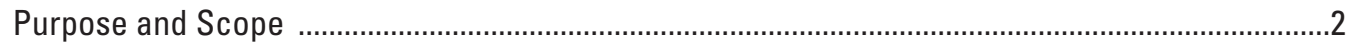

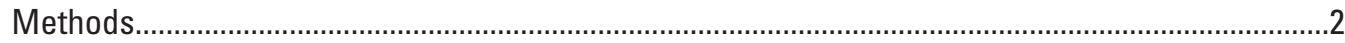

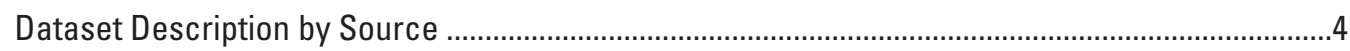

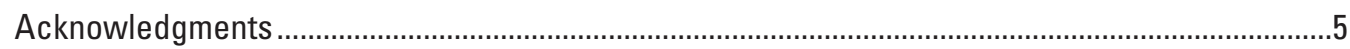

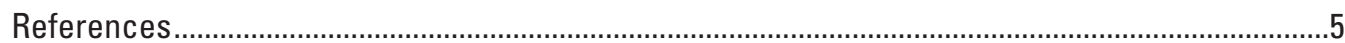

\section{Figures}

1. Map showing areal extent for each source report used in this data series. . .2

2. Generalized correlation chart showing stratigraphic units, hydrogeologic units, and sources for raster surfaces created for this report, Southeastern Coastal Plain .....3

\section{Table}

1. List of databases, raster surfaces, scanned images, and shapefiles with corresponding publication number, figure or plate number, and description

\section{Conversion Factor and Datum}

\begin{tabular}{ccc}
\hline Multiply & By & To obtain \\
\hline foot $(\mathrm{ft})$ & 0.3048 & meter $(\mathrm{m})$ \\
\hline
\end{tabular}

Coordinate information is referenced to the North American Datum of 1927 (NAD 27).

Altitude, as used in this report, refers to distance above the vertical datum. 



\title{
Digital Surfaces and Hydrogeologic Data for Mesozoic through Early Tertiary Rocks in the Southeastern Coastal Plain in Parts of Mississippi, Alabama, Georgia, South Carolina, and Florida
}

\author{
By Debra M. Cannon, Jason C. Bellino, and Lester J. Williams
}

\section{Abstract}

A digital dataset of hydrogeologic data for Mesozoic through early Tertiary rocks in the Southeastern Coastal Plain was developed using data from five U.S. Geological Survey (USGS) reports published between 1951 and 1996. These reports contain maps and data depicting the extent and elevation of the Southeast Coastal Plain stratigraphic and hydrogeologic units in Florida and parts of Mississippi, Alabama, Georgia, and South Carolina. The digital dataset provides hydrogeologic data for the USGS Energy Resources Program assessment of potential reservoirs for carbon sequestration and for the USGS Groundwater Resource Program assessment of saline aquifers in the Southeastern United States.

A Geographic Information System (ArcGIS 9.3.1) was used to construct 33 digital (raster) surfaces representing the top or base of key stratigraphic and hydrogeologic units. In addition, the Geographic Information System was used to generate 102 georeferenced maps scanned from the five reports and a geodatabase containing structural and thickness contours, faults, extent polygons, and common features. The dataset also includes point data of well construction and stratigraphic elevations, and scanned images of two geologic cross sections and a nomenclature chart.

\section{Introduction}

In 2007, the Energy Independence and Security Act (Public Law 110-140) authorized the U.S. Geological Survey (USGS) to conduct a national assessment of potential geologic storage resources for carbon dioxide in cooperation with the U.S. Environmental Protection Agency and the U.S. Department of Energy (Brennan and others, 2010). The USGS also initiated a study in 2010 to assess and map saline aquifers in the Southeastern United States as potential water sources. Information on the depth, thickness, and extent of geologic and hydrologic units is important for assessment of potential saline aquifers and potential reservoirs for carbon sequestration. This report provides a digital dataset of hydrogeologic data for Mesozoic through early Tertiary clastic sedimentary rocks, using data from five USGS reports published between 1951 and 1996. The reports are Circular 91 (Applin, 1951); Professional Paper 447 (Applin and Applin, 1965); Professional Paper 524-G (Applin and Applin, 1967); Professional Paper 1088 (Brown and others, 1979); and Professional Paper 1410-B (Renken, 1996). Prior to this compilation, maps from these older important works were not available in a digital format that would enable rapid and efficient analysis and comparison to other available digital datasets. The dataset will provide valuable hydrogeologic information for both the carbon sequestration and saline aquifer mapping projects. 


\section{Purpose and Scope}

The purpose of this report is to provide digital surfaces of key stratigraphic and hydrogeologic units in the Southeastern Coastal Plain that were derived from five USGS reports published between 1951 and 1996. The study area includes Florida and parts of Mississippi, Alabama, Georgia, and South Carolina. The location of the Southeastern Coastal Plain and the extent of the five report study areas that provided data for this report are shown in figure 1.

A generalized correlation of stratigraphic and hydrogeologic units in this study and their relationship to the 33 digital surfaces presented in this report are shown in figure 2. The digital surfaces represent the top and (or) base of (1) selected major hydrogeologic units including: the Pearl River aquifer, Chattahoochee River and McNairy-Nacatoch aquifers, and the Black Warrior River aquifer, and (2) 28 timestratigraphic units that range from the base of the Mesozoic to the top of the Claibornian.

The scope of this work involved scanning 102 report figures (including 105 georeferenced maps, two cross sections, and a naming chart); creating a geodatabase of 129 vector features representing elevation and thickness contour lines, faults, formation extents and other geologic features of interest; and generating a database containing point data of well construction and stratigraphic elevation data. Table 1 lists the files created for this report by report number, plate or figure number, and includes a brief file description. The report describes methods used to develop the digital surfaces and provides a brief description of the five selected USGS reports and resulting datasets.

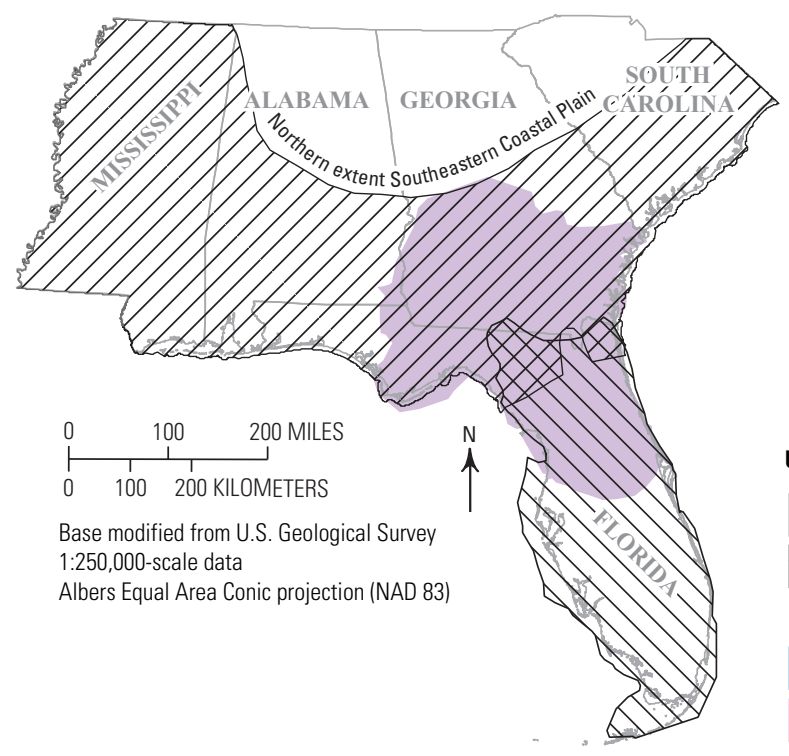

\section{Methods}

Paper maps from the five previously published reports were scanned and georeferenced to the North American Datum of 1927 (NAD 27) using the Lambert Conformal Conic projection (standard parallels 33 and 45 degrees, central longitude -96 degrees, central latitude 39 degrees). Once georeferenced, tracing of pertinent line features contained in each image (for example, contours and faults) was facilitated by specialized software (NeuraMap) using algorithms that automated much of the process. Resulting digital line features were then processed using standard geographic information system (GIS) software (ArcGIS Version 9.3.1) to remove artifacts from the vectorization process and to verify and update attribute tables. The vectorization of polygonal features, such as outcrop area and unit extents, was completed by manually tracing the features from the georeferenced maps into new polygon features in the GIS.

Raster datasets depicting structural surfaces of timestratigraphic and hydrogeologic units were generated by interpolating equidistant point features derived from the polyline features created in the vectorization process. Additionally, barriers were used in the interpolation process so that the relations represented in the original maps regarding geologic features, such as faults and unit extents, were maintained. Raster datasets were created independently of one another, and logical relations between datasets may not be maintained everywhere. Irregularities may exist, especially in areas near edges or where the units are relatively thin. Because the digital datasets are intended to be exact reproductions of the paper maps from which they were developed, no attempt was made to quantify or correct these irregularities.

Figure 1. Areal extent for each source report used in this data series. 


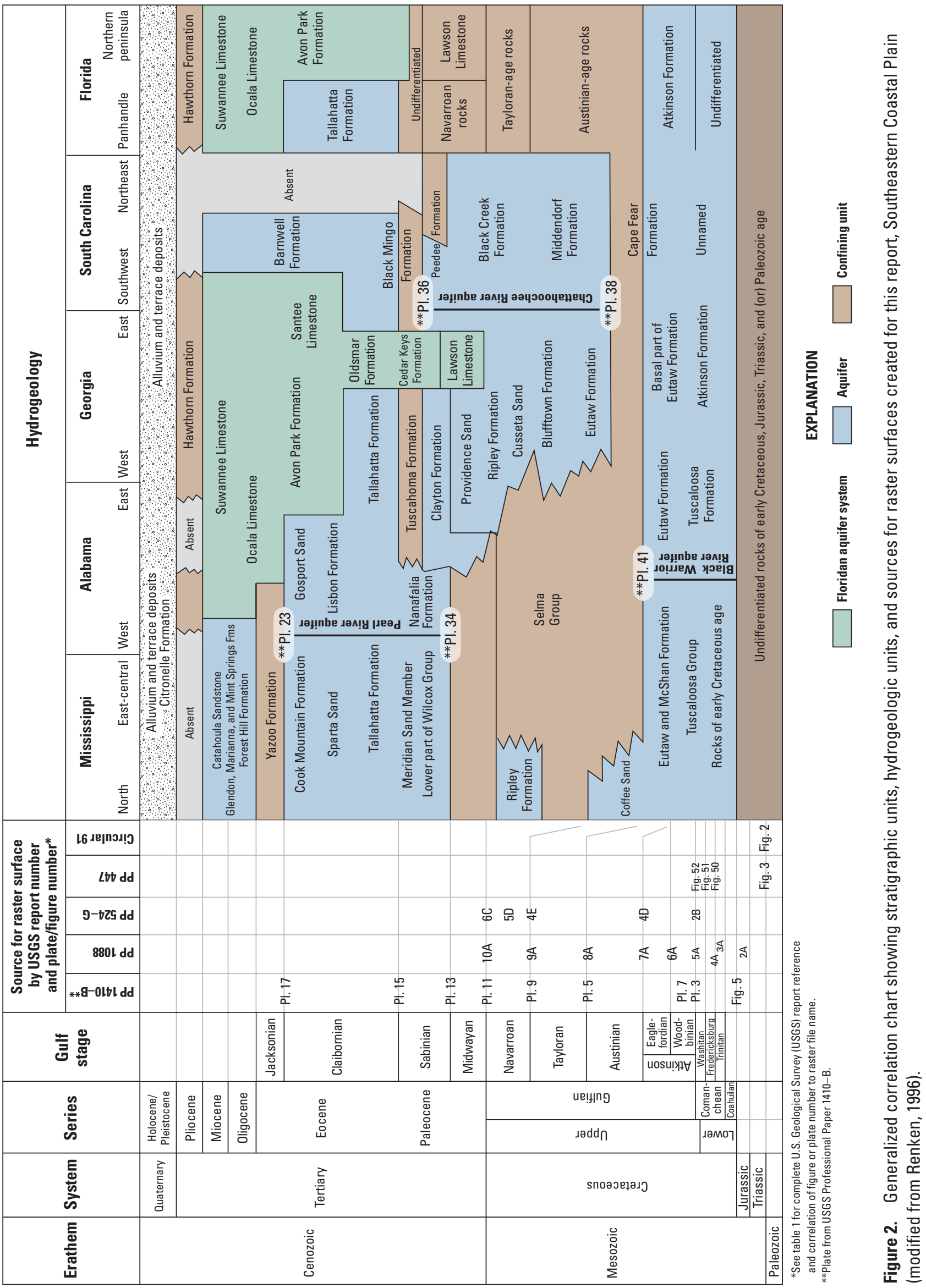


Three reports (Professional Papers 1088, 524-G, and 447) included tables of well construction and stratigraphic data that were used to create the structural surface maps in those reports. These well stratigraphic elevations were compiled for specific units into a database.

\section{Dataset Description by Source}

Datasets for this report originated from five USGS reports whose study areas cover the Southeastern Coastal Plain (fig. 1). A generalized correlation chart shows regional stratigraphic and hydrogeologic units and the 33 raster surfaces that were generated for this report (fig. 2). In addition to the raster surfaces created from structural contour maps, this report includes: 105 georeferenced images created from report figures and plates; a geodatabase containing structural and thickness contours, faults, extent polygon, and other features and; a database of well construction and stratigraphic elevations used as control points for the contour maps.

The report by Applin (1951) used information from 78 oil test wells drilled into pre-Mesozoic rocks that included granite, diorite, metamorphic rocks, rhyolite, pyroclastic rocks, and Paleozoic strata. This information was based largely on petrographic and petrologic studies of cores and cuttings that identified the pre-Mesozoic surface. This surface makes up the floor upon which the Mesozoic stratigraphy was deposited and the one most likely to contain reservoirs and structural features that favor oil and gas accumulation. Files created from the Applin (1951) report include: one digital surface, one scanned and georeferenced report figure, stratigraphic contours, and an extent polygon. Well construction and stratigraphic depth data were not input for this report, because extensive pre-Mesozoic stratigraphic well data are available from other sources.

The report by Applin and Applin (1965) integrated data from 70 scattered test wells (ranging in depth from 4,637 to 15,455 feet) and developed an interpretation of the regional geology in central and southern Florida for Comanche Series rocks, the older rocks of the Coastal Plain floor. The report discusses stratigraphy, structure, micropaleontology, and oil potential of these rocks. Files created from the Applin and Applin (1965) report include: four digital surfaces; 16 scanned and georeferenced images of report figures and plates; stratigraphic contours, extent polygon and faults; and well construction and stratigraphic depth data for 73 wells.

The report by Applin and Applin (1967) presented results of regional stratigraphic and paleontologic studies started in 1943 to identify oil and gas reserves. This report describes the stratigraphy, structure, micropaleontology, lithofacies, and biofacies of the Gulf Series in northern Florida, southern Georgia, and southeastern Alabama, using data from over 150 oil test wells. These data were then integrated into an interpretation of the regional geology. The Gulf Series was divided into four major stratigraphic units from oldest to youngest, the Atkinson Formation (upper and lower members), the beds of Austin age, the beds of Taylor age, and the beds of Navarro age. Files (table 1) created from the Applin and Applin (1967) report include: five digital surfaces; 24 scanned and georeferenced images of report plates; stratigraphic elevation and thickness contours, extent polygons, and faults; and well construction and stratigraphic depth data for 154 wells.

The report by Brown and others (1979) evaluated the geologic and hydrologic factors related to waste-storage potential of late-Jurassic to Cretaceous-age rocks in South Carolina and Georgia (fig. 1). This research was conducted as part of the USGS waste-storage research program to assess potential for deep-well emplacement of liquid waste into deep zones with unusable groundwater (water with a sodium chloride concentration greater than 10,000 milligrams per liter). In addition, the strata must consist of 20 feet or more of porous sand that is directly underlain and overlain by an impermeable layer that is greater than 20 -feet thick. Eight Jurassic to Late Cretaceous geologic units - designated by the letters $\mathrm{H}$ to A and represented in the Brown and others (1979) report by surfaces shown on plates $2 A$ through $10 A$-were judged to have some possible waste-storage potential, with Unit F showing the greatest waste-storage potential. Files (table 1) created from the Brown and others (1979) report include: nine digital surfaces; 36 scanned and georeferenced images of report figure and plates; stratigraphic and thickness contours, unit extent polygon, faults, and sodium chloride concentration contours (Units $\mathrm{G}$ and $\mathrm{F}$ ) for pore volume calculation; and well construction and stratigraphic depth data for 88 wells.

The report by Renken (1996) was published as part of the USGS Regional Aquifer System Analysis (RASA) program and is one report in a series that discusses the hydrogeology, hydrochemistry, and hydrology of the Southeastern Coastal 
Plain aquifer system. This system consists of Cretaceous and Tertiary clastic sedimentary rocks in Mississippi, Alabama, Georgia, South Carolina, and parts of northern Florida and southeastern North Carolina (fig. 1). Renken did not include the Florida Peninsula in his report study area; however, it is considered part of the Southeastern Coastal Plain. The purpose of Renken's report was to produce a regional hydrogeologic framework for use in a Southeastern Coastal Plain regional groundwater flow model. To understand the relation between time-stratigraphic units and regional aquifers and confining units, more than 1,000 oil, gas, and water wells were evaluated and used to format contour and isopach maps and cross sections. Renken found that regional aquifer boundaries do not always correspond to time-stratigraphic boundaries.

All hydrogeologic and stratigraphic contours from the Renken (1996) report were digitized from plates contained in that report, with the exception of the map showing the "Configuration and character of pre-Cretaceous rocks underlying the Southeastern Coastal Plain of the United States" where the original map (Wait and Davis, 1986) was digitized. Files (table 1) created from the Renken (1996) report include 14 digital surfaces representing 9 stratigraphic and 5 hydrogeologic surfaces; 28 scanned and georeferenced images of report figures and plates; and stratigraphic and hydrogeologic contours, fault lines, extent polygons, and other common features. Well construction and hydrogeologic and stratigraphic depth data were not provided in the Renken report.

\section{Acknowledgments}

The digital surfaces and related data for the Southeastern Coastal Plain were compiled in support of several ongoing studies by the USGS including regional assessment of carbon sequestration by the USGS Energy Resources Program (ERP) and mapping of deep saline aquifer systems by the USGS Groundwater Resources Program (GWRP). Appreciation is extended to Peter D. Warwick, with the ERP, Reston, Virginia, who provided much encouragement and support to complete digitization of the surfaces critical to that program. Additionally, a large amount of support was provided by the USGS Office of Groundwater and we especially thank Kevin F. Dennehy of the GWRP for his continued support in completion of the saline mapping project in the southeastern United States.

\section{References}

Applin, P.L., 1951, Preliminary report on buried pre-Mesozoic rocks in Florida and adjacent states: U.S. Geological Survey Circular 91, 28 p., accessed January 7, 2012, at http://onlinepubs.er.usgs.gov/djvu/CIR/circ_91.djvu.

Applin, P L., and Applin, E.R., 1965, The Comanche series and associated rocks in the subsurface in central and south Florida: U.S. Geological Survey Professional Paper 447, 84 p., 11 pls., accessed January 7, 2012, at http:// onlinepubs.er.usgs.gov/djvu/PP/pp_447.djvu.

Applin, P.L., and Applin, E.R., 1967, The Gulf series in the subsurface in northern Florida and southern Georgia: U.S. Geological Survey Professional Paper 524-G, 35 p., 8 pls., accessed January 7, 2012, at http://onlinepubs. er.usgs.gov/djvu/PP/pp_524_g.djvu.

Brennan, S.T., Burruss, R.C., Merrill, M.D., Freeman, P.A., and Ruppert, L.F., 2010, A probabilistic assessment methodology for the evaluation of geologic carbon dioxide storage: U.S. Geological Survey Open-File Report 2010-1127, 31 p., accessed January 7, 2012, at http://pubs.usgs.gov/of/2010/1127/.

Brown, P.M., Brown, D.L, Reid, M.S., Lloyd, O.B., Jr., 1979, Evaluation of the geologic and hydrologic factors related to the waste-storage potential of Mesozoic aquifers in the southern part of the Atlantic Coastal Plain, South Carolina and Georgia: U.S. Geological Survey Professional Paper 1088, 37 p., 11 pls., accessed January 7, 2012, at http://onlinepubs.er.usgs.gov/djvu/PP/pp_1088.djvu.

Neuralog, Inc., 2008, NeuraMap® v2008.12, NeuraMap User Guide-The solution for petroleum data capture: Houston, Tex., 104 p.

Renken, R.A., 1996, Hydrogeology of the Southeastern Coastal Plain aquifer system in Mississippi, Alabama, Georgia, and South Carolina: U.S. Geological Survey Professional Paper 1410-B, 101 p., 42 pls., accessed January 7, 2012, at http://onlinepubs.er.usgs.gov/djvu/ PP/pp_1410_b.djvu.

Wait, R.L., and Davis, M.E., 1986, Configuration and hydrology of the pre-Cretaceous rocks underlying the Southeastern Coastal Plain aquifer system: U.S. Geological Survey Water-Resources Investigations Report 86-4010, 1 sheet, accessed January 7, 2012, at http://onlinepubs. er.usgs.gov/djvu/WRI/wrir_86_4010.djvu. 
Table 1. List of databases, raster surfaces, scanned images, and shapefiles with corresponding publication number, figure or plate number, and description.

[n/a, not applicable; PP, Profesional Paper]

\begin{tabular}{llcl}
\hline $\begin{array}{c}\text { Publication } \\
\text { number }\end{array}$ & $\begin{array}{c}\text { Figure or } \\
\text { plate number }\end{array}$ & File name & Description \\
\hline All & n/a & ds662.gdb.zip & Database files \\
PP 1088, & n/a & ds662_well_data.mdb.zip & $\begin{array}{c}\text { ESRI file geodatabase containing vector and raster data } \\
\text { from all reports } \\
\text { PP 524-G, }\end{array}$ \\
PP 447 & & $\begin{array}{c}\text { Microsoft Access database containing well construction } \\
\text { and stratigraphic elevation data }\end{array}$ \\
\end{tabular}

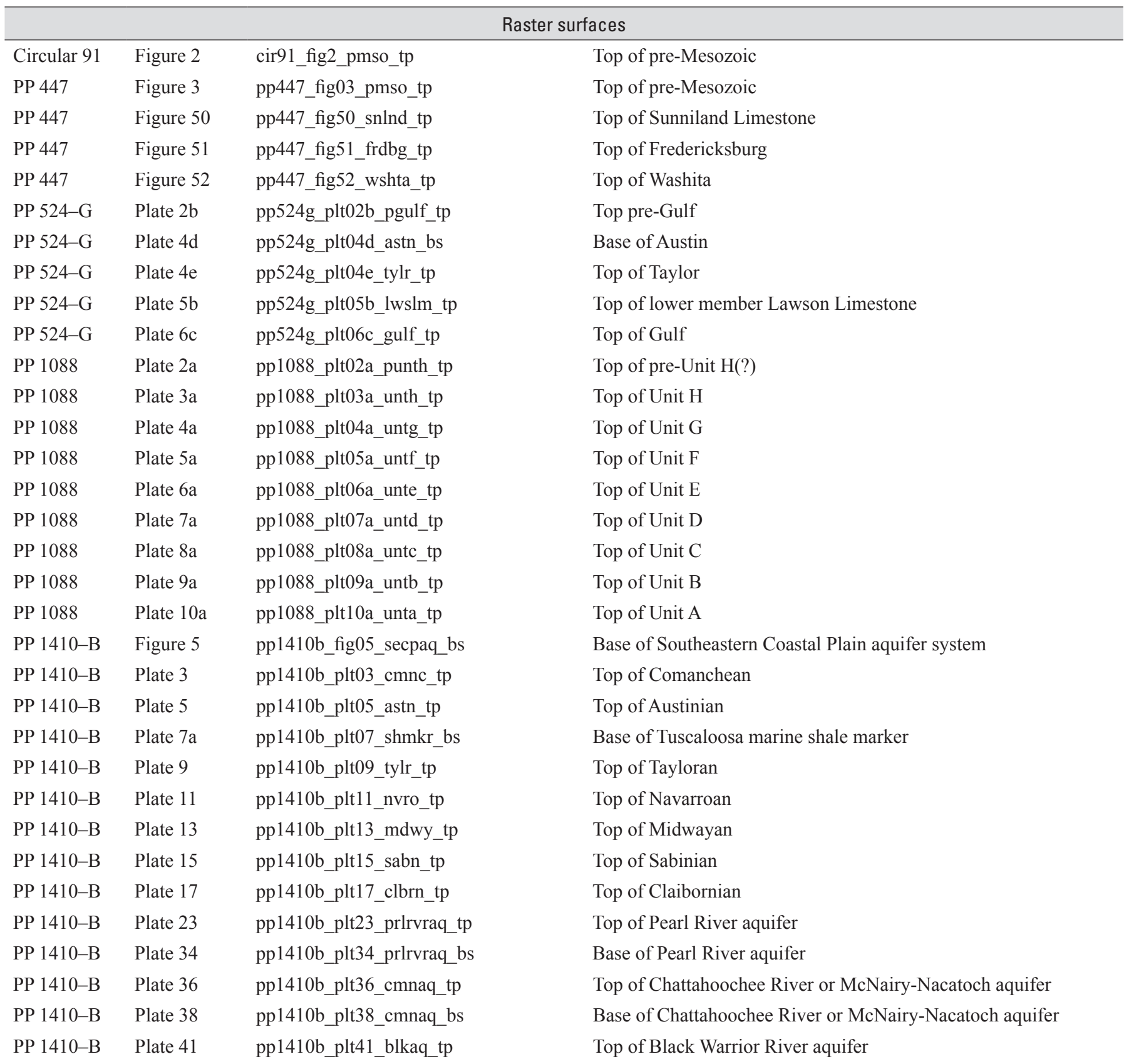


Table 1. List of databases, raster surfaces, scanned images, and shapefiles with corresponding publication number, figure or plate number, and description.-Continued

[n/a, not applicable; PP, Profesional Paper]

\begin{tabular}{|c|c|c|c|}
\hline $\begin{array}{c}\text { Publication } \\
\text { number }\end{array}$ & $\begin{array}{c}\text { Figure or } \\
\text { plate number }\end{array}$ & File name & Description \\
\hline \multicolumn{4}{|c|}{ Scanned images } \\
\hline PP 447 & Figure 1 & pp447_fig01_index_map.tif & Scanned image of study area location \\
\hline PP 447 & Figure 3 & pp447_fig03_pmso_tp.tif & Scanned image of top of pre-Mesozoic \\
\hline PP 447 & Figure 11 & pp447_fig11_cmnc_thk.tif & Scanned image of thickness of Comanche \\
\hline PP 447 & Figure 13 & pp447_fig13_cmncmf_thk.tif & Scanned image of thickness of marginal clastic facies Comanche \\
\hline PP 447 & Figure 27 & pp447_fig27_snlnd_thk.tif & Scanned image of thickness of Sunniland Limestone \\
\hline PP 447 & Figure 35 & pp447_fig35_frdbg_thk.tif & Scanned image of thickness of Fredericksburg \\
\hline PP 447 & Figure 52 & PP447_fig52_wshta_tp.tif & Scanned image of top of Washita \\
\hline PP 447 & Plate $7 \mathrm{a}$ & pp447_plt07a_trnty_thk.tif & Scanned image of thickness of Trinity \\
\hline PP 447 & Plate $7 b$ & pp447_plt07b_etrnty_thk.tif & Scanned image of thickness of early Trinity \\
\hline PP 447 & Plate $7 \mathrm{c}$ & pp447_plt07c_ltrnty_thk.tif & Scanned image of thickness of late Trinity \\
\hline PP 447 & Plate $7 \mathrm{~d}$ & pp447_plt07d_etrnty_tp.tif & Scanned image of top of early Trinity \\
\hline PP 447 & Plate $7 \mathrm{e}$ & pp447_plt07e_ltrnty_tp.tif & Scanned image of top of late Trinity \\
\hline PP 524-G & Plate 1 & pp524g_plt01_well_loc_map.tif & Scanned image of well location map \\
\hline PP 524-G & Plate $2 \mathrm{a}$ & pp524g_plt02a_pgulf_geol.tif & Scanned image of pre-Gulf paleogeology \\
\hline PP 524-G & Plate $2 b$ & pp524g_plt02b_pgulf_tp.tif & Scanned image of top pre-Gulf \\
\hline PP 524-G & Plate $3 f$ & pp524g_plt03f_atksnum_lith.tif & Scanned image of lithofacies of upper member Atkinson \\
\hline PP 524-G & Plate $4 \mathrm{a}$ & pp524g_plt04a_astntylr_thk.tif & Scanned image of thickness of Austin and Taylor age \\
\hline PP 524-G & Plate $4 b$ & pp524g_plt04b_astnchss_thk.tif & Scanned image of thickness of chalky sandstone facies of Austin \\
\hline PP 524-G & Plate $4 \mathrm{c}$ & pp524g_plt04c_astntylr_index_wells.tif & Scanned image of well index for Austin and Taylor \\
\hline PP 524-G & Plate $4 \mathrm{~d}$ & pp524g_plt04d_astn_bs.tif & Scanned image of base of Austin \\
\hline PP 524-G & Plate $4 \mathrm{e}$ & pp524g_plt04e_tylr_tp.tif & Scanned image of top of Taylor \\
\hline PP 524-G & Plate $5 \mathrm{a}$ & pp524g_plt05a_lwslm_thk.tif & Scanned image of thickness of lower member Lawson Limestone \\
\hline PP 524-G & Plate $5 b$ & pp524g_plt05b_lwsum_thk.tif & Scanned image of thickness of upper member Lawson Limestone \\
\hline PP 524-G & Plate $5 \mathrm{c}$ & pp524g_plt05c_nvro_thk.tif & Scanned image of thickness of Navarro \\
\hline PP 524-G & Plate $5 d$ & pp524g_plt05d_lwslm_tp.tif & Scanned image of top of lower member Lawson Limestone \\
\hline PP 524-G & Plate $5 \mathrm{e}$ & pp524g_plt05e_nvro_index_wells.tif & Scanned image of well index for Navarro \\
\hline PP 524-G & Plate 6a & pp524g_plt06a_gulf_geol.tif & Scanned image of geology of Gulf \\
\hline
\end{tabular}


Table 1. List of databases, raster surfaces, scanned images, and shapefiles with corresponding publication number, figure or plate number, and description.-Continued

[n/a, not applicable; PP, Profesional Paper]

\begin{tabular}{|c|c|c|c|}
\hline $\begin{array}{c}\text { Publication } \\
\text { number }\end{array}$ & $\begin{array}{c}\text { Figure or } \\
\text { plate number }\end{array}$ & File name & Description \\
\hline \multicolumn{4}{|c|}{ Scanned images-Continued } \\
\hline PP 524-G & Plate $6 \mathrm{c}$ & pp524g_plt06c_gulf_tp.tif & Scanned image of top of Gulf \\
\hline PP 524-G & Plate $6 \mathrm{~d}$ & pp524g_plt06d_gulf_index_wells.tif & Scanned image of well index for Gulf \\
\hline PP 1088 & Figure 1 & pp1088_fig01_loc_cross_secs.tif & Scanned image of well index map and cross section lines \\
\hline PP 1088 & Plate 1 & pp1088_plt01_x_section.tif & Scanned image of cross sections \\
\hline PP 1088 & Plate $2 \mathrm{a}$ & pp1088_plt02a_punth_tp.tif & Scanned image of top of pre-Unit H(?) \\
\hline PP 1088 & Plate $2 b$ & pp1088_plt02b_untfh_thk.tif & Scanned image of thickness of Units F to $\mathrm{H}(?)$ \\
\hline PP 1088 & Plate $3 \mathrm{c}$ & pp1088_plt03c_unth_sndsh.tif & Scanned image of sand-shale distribution Unit $\mathrm{H}$ \\
\hline PP 1088 & Plate $4 \mathrm{a}$ & pp1088_plt04a_untg_tp.tif & Scanned image of top of Unit G \\
\hline PP 1088 & Plate $4 b$ & pp1088_plt04b_untg_thk.tif & Scanned image of thickness and $\mathrm{NaCl}$ concentration of Unit $\mathrm{G}$ \\
\hline PP 1088 & Plate $4 \mathrm{c}$ & pp1088_plt04c_untg_sndsh.tif & Scanned image of sand-shale distribution Unit G \\
\hline PP 1088 & Plate $5 \mathrm{a}$ & pp1088_plt05a_untf_tp.tif & Scanned image of top of Unit F \\
\hline PP 1088 & Plate $5 b$ & pp1088_plt05b_untf_thk.tif & Scanned image of thickness and $\mathrm{NaCl}$ concentration of Unit $\mathrm{F}$ \\
\hline PP 1088 & Plate $5 \mathrm{c}$ & pp1088_plt05c_untf_sndsh.tif & Scanned image of sand-shale distribution Unit F \\
\hline PP 1088 & Plate $6 a$ & pp1088_plt06a_unte_tp.tif & Scanned image of top of Unit E \\
\hline PP 1088 & Plate $6 b$ & pp1088_plt06b_unte_thk.tif & Scanned image of thickness and $\mathrm{NaCl}$ concentration of Unit $\mathrm{E}$ \\
\hline PP 1088 & Plate $8 b$ & pp1088_plt08b_untc_thk.tif & Scanned image of thickness and $\mathrm{NaCl}$ concentration of Unit $\mathrm{C}$ \\
\hline PP 1088 & Plate $9 \mathrm{a}$ & pp1088_plt09a_untb_tp.tif & Scanned image of top of Unit B \\
\hline PP 1088 & Plate $9 b$ & pp1088_plt09b_untb_thk.tif & Scanned image of thickness and $\mathrm{NaCl}$ concentration of Unit $\mathrm{B}$ \\
\hline PP 1088 & Plate 9c & pp1088_plt09c_untb_sndsh.tif & Scanned image of sand-shale distribution Unit B \\
\hline PP 1088 & Plate $10 \mathrm{a}$ & pp1088_plt10a_unta_tp.tif & Scanned image of top of Unit A \\
\hline PP 1088 & Plate $10 \mathrm{~b}$ & pp1088_plt10b_unta_thk.tif & Scanned image of thickness and $\mathrm{NaCl}$ concentration of Unit A \\
\hline PP 1088 & Plate $10 \mathrm{c}$ & pp1088_plt10c_unta_sndsh.tif & Scanned image of sand-shale distribution Unit A \\
\hline PP 1088 & Plate 11a & pp1088_plt11a_unta_nacl.tif & Scanned image of $\mathrm{NaCl}$ concentration Unit A \\
\hline PP 1088 & Plate $11 b$ & pp1088_plt11b_untb_nacl.tif & Scanned image of $\mathrm{NaCl}$ concentration Unit $\mathrm{B}$ \\
\hline PP 1088 & Plate 11c & pp1088_plt11c_untc_nacl.tif & Scanned image of $\mathrm{NaCl}$ concentration Unit $\mathrm{C}$ \\
\hline PP 1088 & Plate 11d & pp1088_plt11d_untd_nacl.tif & Scanned image of $\mathrm{NaCl}$ concentration Unit $\mathrm{D}$ \\
\hline
\end{tabular}


Table 1. List of databases, raster surfaces, scanned images, and shapefiles with corresponding publication number, figure or plate number, and description.-Continued

[n/a, not applicable; PP, Profesional Paper]

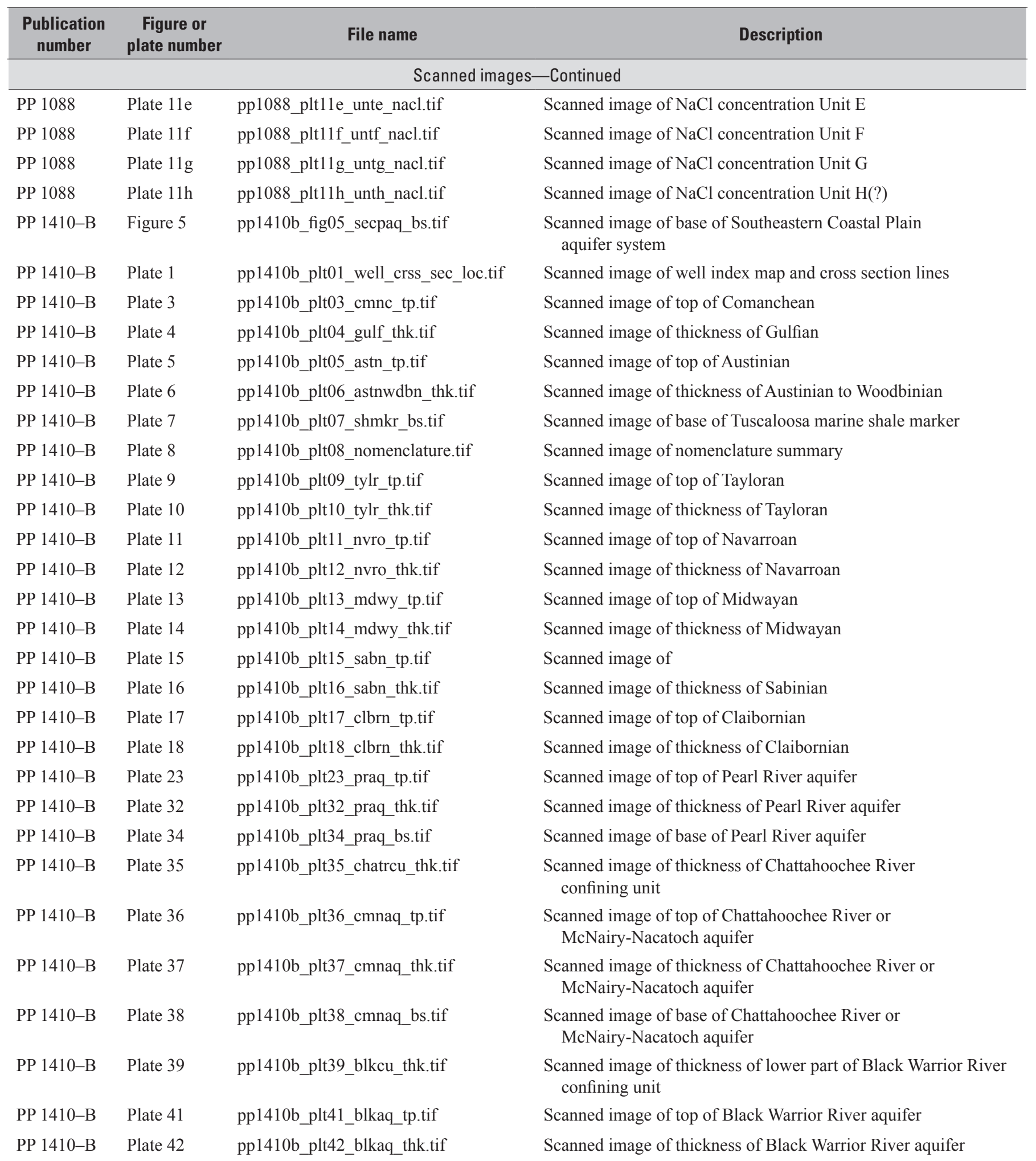


Table 1. List of databases, raster surfaces, scanned images, and shapefiles with corresponding publication number, figure or plate number, and description.-Continued

[n/a, not applicable; PP, Profesional Paper]

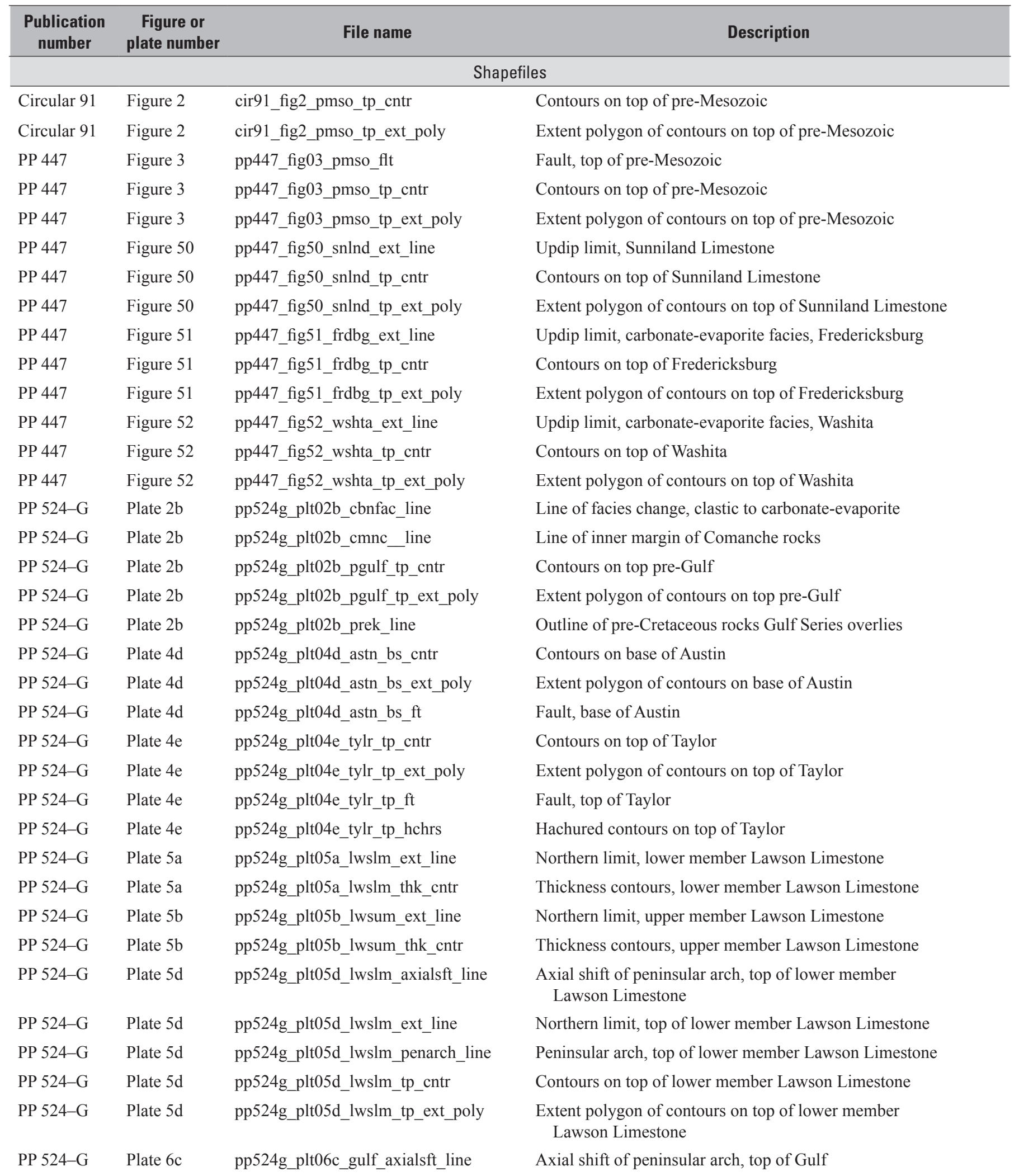


Table 1. List of databases, raster surfaces, scanned images, and shapefiles with corresponding publication number, figure or plate number, and description.-Continued

[n/a, not applicable; PP, Profesional Paper]

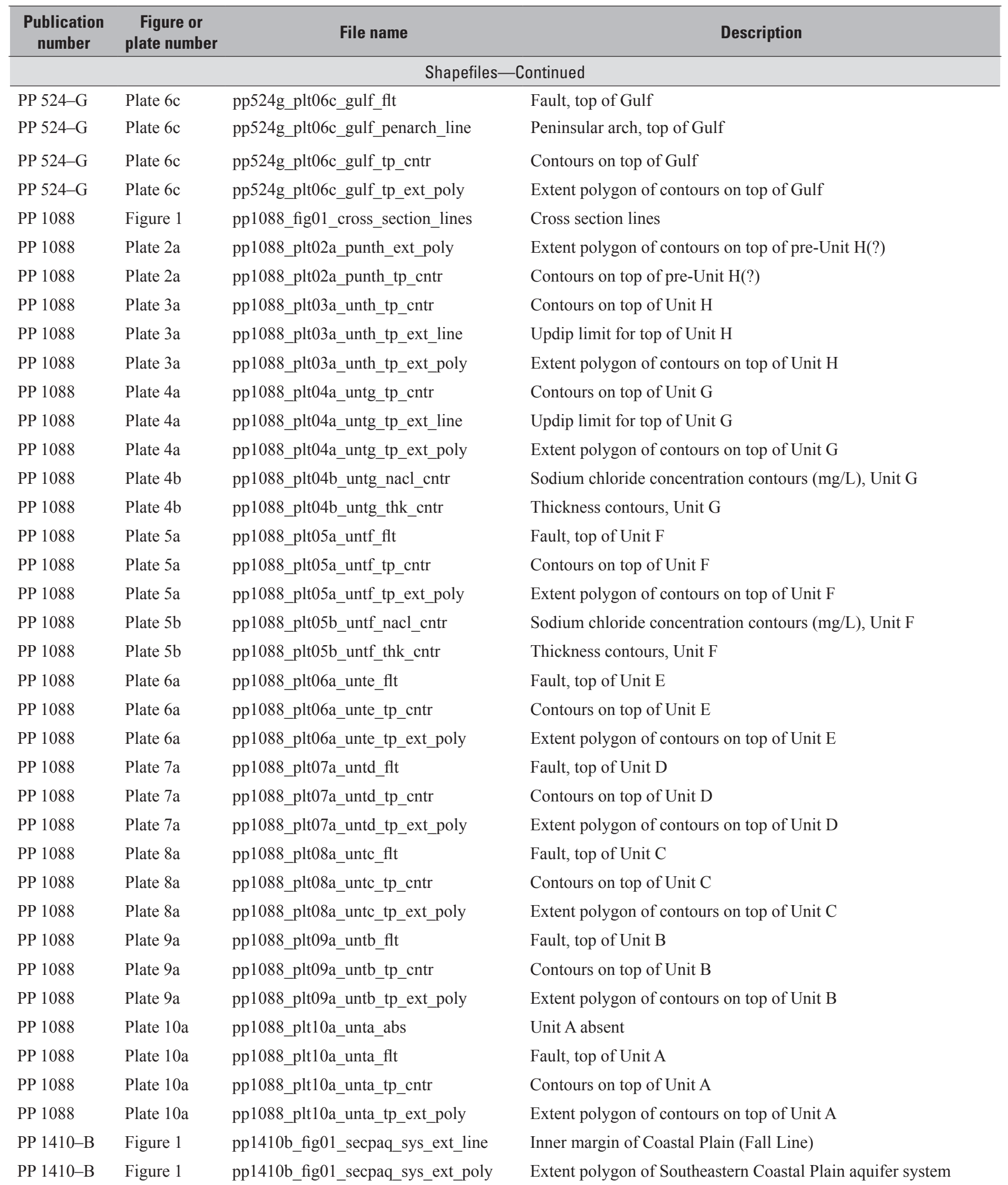


Table 1. List of databases, raster surfaces, scanned images, and shapefiles with corresponding publication number, figure or plate number, and description.-Continued

[n/a, not applicable; PP, Profesional Paper]

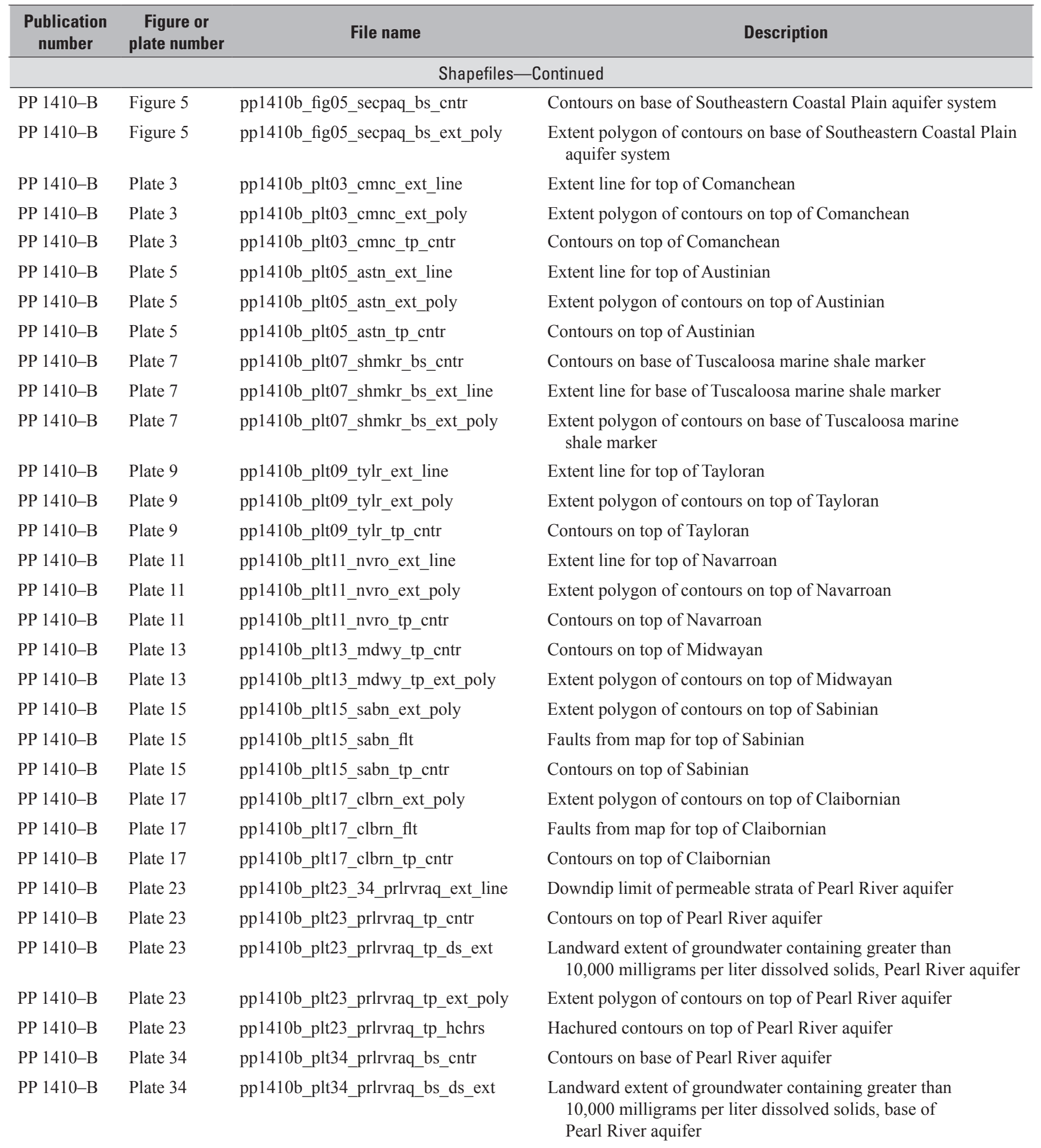


Table 1. List of databases, raster surfaces, scanned images, and shapefiles with corresponding publication number, figure or plate number, and description.-Continued

[n/a, not applicable; PP, Profesional Paper]

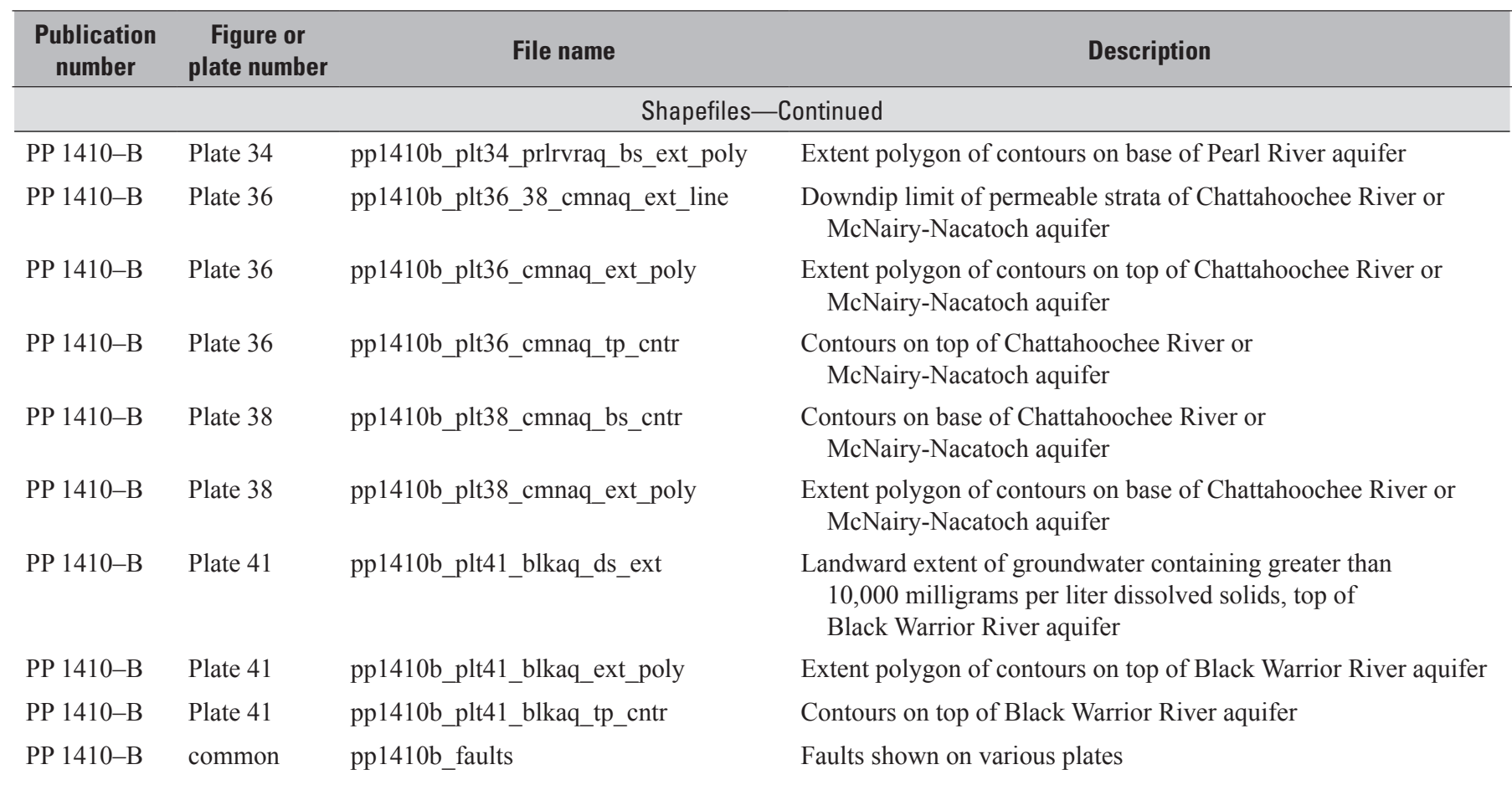

\section{References}

PP 1410-B Renken, R.A., 1996, Hydrogeology of the Southeastern Coastal Plain aquifer system in Mississippi, Alabama, Georgia, and South Carolina: U.S. Geological Survey Professional Paper 1410-B, 101 p., 42 pls., accessed January 7, 2012, at http://onlinepubs.er.usgs.gov/djvu/PP/pp_1410_b.djvu.

PP 1088 Brown, P.M., Brown, D.L, Reid, M.S., Lloyd, O.B., Jr., 1979, Evaluation of the geologic and hydrologic factors related to the waste-storage potential of Mesozoic aquifers in the southern part of the Atlantic Coastal Plain, South Carolina and Georgia: U.S. Geological Survey Professional Paper 1088, 37 p., 11 pls., accessed January 7, 2012, at http://onlinepubs.er.usgs.gov/djvu/PP/pp_1088.djvu.

PP 524-G Applin, P.L., and Applin, E.R., 1967, The Gulf series in the subsurface in northern Florida and southern Georgia: U.S. Geological Survey Professional Paper 524-G, 35 p., 8 pls., accessed January 7, 2012, at http://onlinepubs.er.usgs.gov/djvu/PP/pp_524_g.djvu.

PP 447 Applin, P.L., and Applin, E.R., 1965, The Comanche series and associated rocks in the subsurface in central and south Florida: U.S. Geological Survey Professional Paper 447, 84 p., 11 pls., accessed January 7, 2012, at http://onlinepubs.er.usgs.gov/djvu/PP/pp_447.djvu.

Circular 91 Applin, P.L., 1951, Preliminary report on buried pre-Mesozoic rocks in Florida and adjacent States: U.S. Geological Survey Circular 91, 28 p., accessed January 7, 2012, at http://onlinepubs.er.usgs.gov/djvu/CIR/circ_91.djvu. 
Manuscript approved on December 22, 2011

For more information about this publication, contact: USGS Georgia Water Science Center

3039 Amwiler Road

Atlanta, GA 30360

telephone: $770-903-9100$

http://ga.water.usgs.gov/

Edited by Twila D. Wilson

Layout by Caryl J. Wipperfurth 
